Journal of Library Services and Technologies, 2(1), 30-40, January 2020

ISSN: 2616-1354 (Print) 2636-7424 (Online) Available online at credencepressltd.com

DOI: $\underline{10.47524 / j 1 s t . v 2 i 1.3}$

\title{
The use of online legal information access and retrieval devices in the e- library of the Faculty of Law, University of Calabar, Nigeria
}

\author{
Juliana Nwakaego Agwunobi \\ Science and Technology Library \\ University of Calabar, Nigeria \\ E-mail: julianaagwunobi@gmail.com \\ Cell: +2348034762987 \\ Pius Tom Umoren \\ Law Library \\ University of Calabar, Nigeria \\ E-mail: pius.umoren@gmail.com; umoren.pius@gmail.com
}

\begin{abstract}
This study examined the availability of online legal information access and retrieval devices and their utilization in the e-library of the Faculty of Law, University of Calabar. To aid the study, the faculty of law students constituted the population of study. Of this 433 students formed the sample of the study being the bona fide law library registered students who completed and returned the questionnaire. The research instrument for data collection was a structured questionnaire. The instrument was designed to elicit information on the availability of fifteen online legal information and access devices in the e-library library and the extent of their utilization in accessing and retrieving legal information in the library. Findings reveal that although the e-library library had a number of the sampled online access and retrieval devices there were disparities in their usages by the students. The disparity in the utilization of these devices stemmed from the fact that some were heavily utilized than others, while some were nonexistence. The study further showed that but for the manifest problems that affected the usages of the devices, the level of patronage implied that the e-library seems to be the in-thing in contemporary information search and access for possible utilization to meet desired goals.
\end{abstract}

Keywords: Legal information access, E-library, Retrieval devices, University of Calabar, Nigeria

\section{Introduction}

It is trite that the world is constantly changing hence the advent of technologies in relevant spheres to aid life and utilization of the variety of teaching and learning aids for acquisition of new knowledge. This position affects every sphere of human information and communication endeavours.

According to Ajetunmobi (2017), the last fifteen years have witnessed tremendous progress in computer technology application in the creation of infrastructure for the emerging electronic market place. This, he summarizes, has resulted in the various forms of online conducts on daily basis such as purchasing of digital contents, software applications as well as website designs, etc.

In another perspective, Ajetunmobi (2017) viewed information as the product of human interactions with the environment. This interactions, according to him, include 
Juliana Nwakaego Agwunobi and Pius Tom Umoren: Legal information environment and utilization of eresources by undergraduate students at E-library, Faculty of Law, University of Calabar, Nigeria

data, laws and procedures, emotional responses as well as statement of morality and ethics as produced and communicated by human beings interacting with the world and each other. He then espouses that in ICT parlance, information is an act of informing or communicating knowledge to a person with the necessary background to decode the message so communicated for ultimate utilization to meet his information need.

From this stand point, it is clear that every user of the law library seeking legal information cannot be said to be selfsufficient in terms of his prior knowledge without recourse to a stakeholder let alone the entire legal information market place.

This is why the sponsors of legal education are setting up $e$-libraries to aid their clients whether of students or other researchers to easily interact with online resources in these law libraries for ultimate use.

\section{Purpose of the study}

This study therefore investigated the e-legal information environment in terms of the availability of access and retrieval devices or search engines and to what extent these are utilized by clients.

\section{Research questions}

1. What are the available information search and retrieval devices in the $e$-library of the University of Calabar?

2. What are the most used information search and retrieval tools in the $\mathrm{e}$ library?

3. How can the utilization of the information search and retrieval devices be improved?

\section{Literature review}

Although the common image of academic and other law libraries is rows and rows of shelves packed with volumes of books, neatly arranged, the impact of databases on legal research and the law library has become an imperative phenomenon (Dada, 2000). The need for an automated law library in contemporary times cannot be overlooked, because according to JohnOkeke (2003), advances in information technology have incessantly invaded virtually every aspect of human endeavour. This has made advantages of full text electronic access to the materials of law for research apparent. Thus, large databases of primary source materials have been acquired by developed law libraries and lawyers to aid research and the practice of law. According to Haavisto (1996), one interesting thing about database is that they offer new potentials that seriously challenge traditional professionalism within the library setting.

The growth in the amount of accessible on-line legal information has allowed many law libraries and other library users to reduce the number of printed copies of primary source materials in their collections. The same applies to secondary sources where legal materials and other finding tools such as abstracts, author/titles, indexes, bibliographies, etc., are now available on-line. Therefore what is fast gaining grounds now is that there is an increasing accessibility of legal information in both primary and secondary source materials through the information and communication technology (ICT) network electronic systems.

Law librarianship is a quintessential aspect of library and information practice as its practitioners are expected to be professionals. In this context, Lawal et al. (2008) posit that law librarianship with its professional traits rests "on the need for legal information support in the education, training, development, research and prosecution of the law". The competence of a lawyer in practice, derives from efficient 
Juliana Nwakaego Agwunobi and Pius Tom Umoren: Legal information environment and utilization of eresources by undergraduate students at E-library, Faculty of Law, University of Calabar, Nigeria

and constant supply of legal information in the print and non-print formats to sustain such competence. Anigilaje (2005) surported this position where he stated that regardless of the information on need-site, such as in classrooms, courts, judicial offices, bench, bar, or in the overall society, the wholesome functioning of the legal practitioner rests squarely on his ability to access relevant and current legal information.

Consequently, Ugboma (2005) noted that law must be at the disposal of the legal practitioner when he has need to access any information of choice. Of course, the American Association of Law Librarians (2003) notes that the world of legal information is rapidly moving to the electronic environment. Omekwu (2005) posited that the various digital formats are not only numerous but enriching.

With this development, Daner (2002) stated that, "as increasing amount of primary legal materials are issued primarily or exclusively in electronic formats, academic law library will be increasingly challenged to define their role in ensuring that those materials are preserved for future researchers". This position is very true because according to Trivedi and Joshi (2003) there is an incredible sense of digital divide as well as weak conditions and inadequate connectivity to the internet. The implication of this, according to them, is that law libraries should brace up to providing resources in technology, capital and human, to make the difference.

Therefore, with ICT, Bassey and Ani (2015) observed that modern libraries now move from information 'holding' to 'accessibility', making the development of electronic library mandatory. In the same vein, Ellis and Oldman (2005) noted that with the ICTs, libraries can access and store the majority of information on electronic form thereby making them available to users online. Thus online information environment will easily facilitate accessibility and utilization of information by library users to tackle their information needs. This position is supported by Ani (2013) who described electronic information environment (EIE) as that which is significantly characterized with application of the ICT in the university libraries to support access and use of information in learning, teaching and research.

With e-library as a legal information environment, law students and other users must have access to its information resources online without necessarily visiting the physical library. As an e-library, the scope of its services must incorporate the two major information services which are:

(i) Online catalogue services and

(ii) Provision of online tools, by which search engines are major access and utilization mechanisms.

Nwosu and Ottong (2014) suggested the following as services online catalogue should basically provide: title, author and subject catalogues. The authors go further to include search engines, subject directories and Meta-search Tools as online searching tools. Emphasizing the importance of search engines, Reitz (2005) opined that search engines are created databases of web pages that help a searcher find specific information on any given subject.

Therefore, for any e-library to function optimally in the discharge of its information delivery services, there must be availability of these core services to clients. The New Encyclopedia Britannica 6 (1998) supported this position by stating that internets is the most reliable, fastest and widest means by which information seekers can access and utilize information resources. In this wise e-libraries must be seen to function as efficiently as true legal 
Juliana Nwakaego Agwunobi and Pius Tom Umoren: Legal information environment and utilization of eresources by undergraduate students at E-library, Faculty of Law, University of Calabar, Nigeria

information custodians and managers within the contemporary global context.

Rahman (2002) stated that e-library is a library with electronic information resources in its collection stored electronically and are accessible only through electronic systems and networks. They go on to say that electronic information resources include information materials such as electronic books (e-books), electronic journal (e-journals), electronic conference papers, electronic conference proceedings, electronic newspapers and/or magazines, electronic technical reports and online databases among others. Seeker (2004) averred that from the perspective of e-libraries, e-books do not require shelves and shelf-spaces. E-library search engines therefore are access tools to online legal information materials stored in electronic system and databases.

Bassey and Ani (2015) stated that online database in a collection of different ejournals/e-books' titles which when subscribed to by institutions can be accessible to users in their electronic libraries. The authors list examples of online databases to include AGORA, EBSCO HOST, HINARI and Science Direct, etc.

In the context of e-library collection, Hamza (2001) stated that the databases in these libraries will include the full text of many thousands of reported cases, statutes and other legal instruments. He goes on to add that legal databases in the UK and US are Lexis and Prestel respectively. In Nigeria popular legal databases are the Lexis Nexis, the West law, the NUC virtual library and Law pavilion (Legal Pedia) among others. Some of these databases are accessible to users upon subscription. However, Nigeria is a major beneficiary of the open access online journals because Bassey and Ani (2015) observed that these journals can be accessed directly on the internet with no financial cost. Legal databases as a prominent feature of an elibrary, play important roles in aiding the accessibility and utilization of legal information for the legal profession and training. This will be made effective where the library has in its electronic infrastructures functional search engines and devices for online information search, access and retrieval undertakings.

In a study to ascertain whether the library has continued to remain only a store house of physical bibliographic materials, Rahman (2012) found out that the library has gotten a new outlook in this era of the ICT. The study had as its prime objective to find out whether library users assess online materials through available search engines in the libraries of study. The findings of the study were that the emergence of the ICT has brought about the establishment of elibraries with e-collection search and utilization tools to access online materials in the internet. The study also found out that elibrary users were able to access e-materials through different search services for ebibliographic information, e-subject/title information as well as e-indexes information thereby being able to utilize information resources for their research works.

Sloan (2008) noted that the quickest and best retrieval device that provides answers to students' queries in university libraries is the internet. This, he contends, also offers almost limitless possibilities for reference services in libraries. Obasuji (2006) maintained that the internet is a major educational resource where anybody can go to learn one thing or the other as well as acquire and exchange information for development. Ojokoh and Osaolu (2005) however, revealed four major problems that tend to hinder effective use of internet retrieval device by students who make use of information resources in university libraries. The problems are: 
Juliana Nwakaego Agwunobi and Pius Tom Umoren: Legal information environment and utilization of eresources by undergraduate students at E-library, Faculty of Law, University of Calabar, Nigeria

(i) Inadequate provision of access infrastructure to the internet Inadequate searching skills on the part of students themselves Inadequate points of internet use in the university campus

Exorbitant cost of internet use and high access subscription cost

The authors therefore recommend that internet facilities in university libraries and cyber cafes should be properly managed to ensure effective information delivery operations as well as provision of services at affordable cost to students. What this implies is that to aid access, retrieval and utilization of information materials and resources available in university libraries and cyber cafes, appropriate search engines should form part of the management output. This alone will assist students and other seekers of information to achieve their needs.

Nnadozie (2014) observed that some libraries are helping in the organization of the internet for seekers of online information who set their sights on digital information. Harms (2014) gives example of information search strategy where he states that using the asterisk to perform fill-in-the-blank searches is a useful search technique which is a database. This, he says, contains library's information that can only be accessed online for utilization by anyone. Thus standard academic law libraries can offer e-journals in any subject area of law to their users.

OPAC as a more effective search engine for online search and retrieval functions, Odini (1994) had compared the performance of two annual indexes and three related online databases in information retrieval devices. The methods used for data collection were interview with the user and observing the guides to the databases as well as noting the file numbers of the three databases to be searched. The finding revealed that the best source for the search of topics was found to be the online database. The reason for this was because the search of topics in 96 copies of engineering index was faster, thorough and efficient and was accomplished in about one and half hours as against one whole week of manual search of the same volumes.

Olanlokun and Ojo (1998) carried out a random sampling of books, monographs and documents published in Nigeria from 1986-1996 available in the University of Lagos, and can be accessed online. The purposes of the survey were:

(i) To identify the materials covered with regard to subject areas

(ii) Category of publishers whether multinational or purely indigenous

(iii) Differences in indexing of items in the 1980s and 1990s.

The result of the findings was that the multinational companies fared better in their published information materials which can be accessed online through the library's search engines as against information materials published by purely indigenous companies. Oyedum (2007) undertook a study to determine the importance of internet services in the academic achievement of students in the Federal University of Technology, Minna, The researcher sought to find out:

$$
\begin{aligned}
& \text { Academic performance of } \\
& \text { students } \\
& \text { The extent to which students } \\
& \text { have access to internet } \\
& \text { facilities in the university and } \\
& \text { The extent of students' } \\
& \text { satisfaction with the libraries } \\
& \text { internet services. }
\end{aligned}
$$

The study revealed that though the Federal University of Technology at the time was not computerized, internet and 
Juliana Nwakaego Agwunobi and Pius Tom Umoren: Legal information environment and utilization of eresources by undergraduate students at E-library, Faculty of Law, University of Calabar, Nigeria

other electronic online services were provided for students in the library through a cyber café. As to how this arrangement affected the students, the researcher discovered that the arrangement tremendously improved the academic performance of students in the institution. The study recommended that the charge for the digital services provided should be moderate to encourage students' continuous patronage.

Adesoye and Oyintola (2009) investigated the use of the e-library by graduate students in accessing and retrieving information for research. The purpose of the study was to find out the extent of graduate students' knowledge of information retrieved and their searching problems. It was found out that majority of the graduate students were aware of using available search engines in the e-library to access and retrieve information. The study further revealed that graduate students also recognized the usefulness of these devices in utilizing library resources to meet their information needs online. The study recommended that user education on the use of ICT, be further developed to enhance the graduate students' skills on information search and usage.

Ray and Day (2008) noted that new technologies such as the internet and other electronic databases are more innovative systems for information, access. These, they posit have made the library and other information centres complicated and challenging to libraries and readers. They go further to say that these innovations are now imposing new responsibilities on library users and practitioners where they are imposing new responsibilities on library users and practitioners where they are expected to acquire new search skills to be able to utilize the resources available in the library. Supporting this view Ayifureke (2010) opined that libraries now are employing new technologies for purposes of improving productivity, giving better customer satisfaction and quality information delivery services in academic libraries. Enumerating the importance of internet to libraries, Tadasad (2009) maintained that the internet has become a part of library environment which has added value to the libraries information services.

Oyenelle (2007) undertook a study on the role of the ICT in the discharge of library functions and came up with a finding that internet is playing a very important role in the discharge of library functions including amongst others, acquisition and dissemination of information. According to him, with more documents published online and internet resources growing at $18 \%$ monthly, libraries now shift their content emphasis to e-collections. This, therefore, makes provision of online search engines mandatory to assist users in their search and utilization of information resources in the library. Of course, the Law library must not be an exception in thiscrave for digitized collection.

The E-Library of the University of Calabar came into being as a separate and distinctive library but remained part of the Law Library in 2015. The establishment of the Library was to meet the NUC and CLE's Benchmark as stipulated for tertiary institutions offering law programme in the country.

The e-library of the Faculty of Law, University of Calabar has quiet a good number of e-devices available to its law students and other clients. In specific legal information terms users of the e-library can access legal information online using search engines of the law pavilion, Lexis Nexis, Jstor, NUC virtual library, EBSCO HOST as well as Easy law. In general terms with regard to other websites with both legal and non-legal information resources, e-library clients can also access legal materials of 
Juliana Nwakaego Agwunobi and Pius Tom Umoren: Legal information environment and utilization of eresources by undergraduate students at E-library, Faculty of Law, University of Calabar, Nigeria

other databases from the main University library website where there is internet connectivity. Such websites include AGORA, Oxford Journal Online, HINARI, INFOTRA as well as OCLC, among others.

\section{Methods}

This study adopted the survey research design methodology as instrument for data collection. This was designed to elicit information from respondents with regard to the availability of search, access and retrieval devices in the e-library of the Faculty of Law, University of Calabar based on the 15 types listed on the questionnaire on the first part and on the second part, the instrument was also designed to elicit information with regard to extent of utilization of these search devices as well as how to improve upon their usages for legal information access and retrieval in the elibrary. The registered students of Faculty of Law served as the respondents which was the population of study. Of the 850 registered students, $433(50.9 \%)$ of the respondent students served as the sample of the study.

\section{Results and discussion}

The results of the study and analyses are presented based on the research questions as follows:

Research question 1: What are the available information search and retrieval tools in the e-library, Faculty of Law, University of Calabar?

The data in Table 1 are used to answer this question.

\begin{tabular}{|c|c|c|c|}
\hline $\mathbf{S} / \mathbf{N}$ & Search/retrieval engines & Frequency & Percentage \\
\hline 1. & AGORA & 80 & 18.4 \\
\hline 2. & EBSCO HOST & 413 & 95.3 \\
\hline 3. & Easy Law & 293 & 67.6 \\
\hline 4. & Directory of Open Access Journal & 00 & 00 \\
\hline 5. & INFOTRAC & 33 & 7.6 \\
\hline 6. & HINARI & 120 & 27.7 \\
\hline 7. & GOOGLE SCHOLAR & 207 & 47.8 \\
\hline 8. & JSTOR & 390 & 90 \\
\hline 9. & NUC Virtual Library & 410 & 94.6 \\
\hline 10. & Lexis Nexis & 420 & 96.9 \\
\hline 11. & Law Pavilion & 417 & 96.3 \\
\hline 12. & $\begin{array}{l}\text { Online Computer Library Centre } \\
\text { (OCLC) }\end{array}$ & 00 & 00 \\
\hline 13. & Online Public Access Catalogue (OPAC) & 370 & 85.4 \\
\hline 14. & Oxford Journal Online & 00 & 00 \\
\hline 15. & MetaPress & 00 & 00 \\
\hline 16. & Others & 13 & 3 \\
\hline
\end{tabular}

Findings in Table 1 show that of the fifteen (15) e-search devices and retrieval devices the clients of the e-library found eleven of these of which seven devices were heavily used for their academic work.
This amounted to $73.3 \%$ of the sampled e-library devices. The breakdown of findings revealed that Lexis Nexis (96.9\%) Law Pavilion (96.3\%) Ebsco Host (95.3\%), NUC Virtual Library (94.6\%), 
Juliana Nwakaego Agwunobi and Pius Tom Umoren: Legal information environment and utilization of eresources by undergraduate students at E-library, Faculty of Law, University of Calabar, Nigeria

JSTOR (90\%) and the Online Public Access Catalogue (OPAC) (85.4\%) were heavily used. The findings also revealed that clients of the e-library utilized Easy Law (67.6\%) followed by Google Scholar (47.8\%) as well as HINARI $(27.7 \%)$. AGORA (18.4\%) and INFOTRAC (7.6\%) made the rear in terms of their utilization. According to the findings the Directory of Open Access Journal, Oxford Journal Online and Metapress representing $3 \%$ of the e-library devices that were non-existent and as such were not used. Appraising the result of the findings of Table 1 in line with research question one, the study showed that the e-library of the Faculty of Law, University of Calabar has in its stock 11 e-search tools out of the 15 sampled representing $73.3 \%$ of the sampled search tools. It therefore implies that the elibrary environment of the Faculty of Law E-library, University of Calabar is researchfriendly for the Law students specifically and the other researchers in the University of Calabar.

Research question 2: What are the most used information search and retrieval tools in the e-library, Faculty of Law, University of Calabar?

The data in Table 2 are used to answer this question.

\begin{tabular}{|c|c|c|c|c|}
\hline $\mathbf{S} / \mathbf{N}$ & Search/retrieval engines & & Frequency & Percentage \\
\hline 1. & Lexis Nexis & & 420 & 96.9 \\
\hline 2. & Law Pavilion & & 417 & 96.3 \\
\hline 3. & Ebsco Host & & 413 & 95.3 \\
\hline 4. & NUC Virual Library & & 410 & 94.6 \\
\hline 5. & JSTOR & & 390 & 90.0 \\
\hline 6. & $\begin{array}{l}\text { Online Public Access } \\
\text { (OPAC) }\end{array}$ & Catalogue & 370 & 85.4 \\
\hline 7. & Easy Law & & 293 & 67.6 \\
\hline 8. & Google Scholar & & 207 & 47.8 \\
\hline 9. & HINARI & & 120 & 27.7 \\
\hline 10. & AGORA & & 80 & 18.4 \\
\hline 11. & INFOTRAC & & 33 & 7.6 \\
\hline 12. & Others & & 00 & 00 \\
\hline
\end{tabular}

Findings in Table 2 show that out of the 15 sampled search tools 11 were variously and varyingly used. The table shows that Lexis Nexis was the most used by $420(96.9 \%)$ respondents. This was followed by Law Pavilion by 417 (96.3\%), Ebsco Host - 413 (95.3\%) and NUC Victual Library - 410 $(94.6 \%)$. Also showing regularity of use according to Table 2 are the following search tools: JSTOR - 390 (90\%), Online Public Access (OPAC) - 370 (85.4\%), Easy Law 293 (67.6\%), and Google Scholar 207 $(47.8 \%)$.
According to the findings in Table 2 HINARY, AGORA and INFOTRAC were patronized by $120(27.7 \%), 80(18.4 \%)$ and $33(7.6 \%)$ respectively. The other sampled tools were not available and as such not used. Appraising these findings with regard to the purpose of the study, it is very clear that the Legal information environment of the E-Library, Faculty of Law, University of Calabar enhanced access and utilization of e- legal formation by the respondents. 
Juliana Nwakaego Agwunobi and Pius Tom Umoren: Legal information environment and utilization of eresources by undergraduate students at E-library, Faculty of Law, University of Calabar, Nigeria

Research question 3: How can the utilization of the information search and retrieval devices be improved?

The data in Table 3 are used to answer this question.

Table 3: Respondents' suggestions for the improvement in the utilization of online search access and retrieval devices in the $E$ library

\begin{tabular}{|c|c|c|}
\hline Suggestions & Frequency & Percentage \\
\hline Adequate supply of electricity & 425 & 96.9 \\
\hline Provision of skilled e-library professional & 380 & 87.7 \\
\hline Programme for training of e-library users & 250 & 57.7 \\
\hline Timely subscription of access fees & 430 & 99.3 \\
\hline $\begin{array}{l}\text { Need for replacements and maintenance } \\
\text { culture }\end{array}$ & 370 & 85.4 \\
\hline $\begin{array}{l}\text { Provision of more e-devices and } \\
\text { computers to aid use }\end{array}$ & 409 & 94.4 \\
\hline Need for impress & 120 & 27.7 \\
\hline Support from alumni and philanthropies & 170 & 39.2 \\
\hline
\end{tabular}

Table 3 shows suggestions made by the elibrary clients as to how the library can be improved to enhance their optimum use. Table 3 shows that the largest number of the client respondents have suggested that the elibrary sponsors should ensure timely subscription of Access fees (99.3\%). This was followed by suggestions for adequate supply of electricity (96.9\%), provision of more e-devices and computers to aid use (94.4\%) and provision of skilled e-library professional $(87.7 \%)$.

Still proffering suggestions $57.7 \%$ of the clients agree that there should be need for training programme for e-library users. This accords with Taiwo (2017) where he stated that research is not conducted with a slack or an empty mind. This implies that for elibrary users to be optimum in their research work through the use of available search devices, they need some form of orientation through training in the use of e-access and retrieval devices.

The findings also show that $39.2 \%$ of the respondents agree that the e-library should be supported by the alumni and philanthropists with donations of computer sets and other e-devices. Such assistance will make the library well equipped for satisfactory research work. Suggestion with regard to whether there is need for imprest for the e-library only $27.7 \%$ of the respondents reacted positively to this.

\section{Conclusion}

This study inquired into the availability and utilization of online access and retrieval devices in the e-library of the University of Calabar. From the study it is evident that more than half of the sampled access and retrieval devices were available in the law library. The study also showed that apart from the non-utilization of some of the sampled devices as a result of nonexistence, the level of patronage and utilization of the available devices ranked very high. This situation implies that if adequate improvement based on the suggestions is given, research and other academic works in the e-library will be efficient, effective and satisfying.

In the light of the findings, it is recommended as follows:

1. Every stakeholder in the affairs of the e-library should join hands 
Juliana Nwakaego Agwunobi and Pius Tom Umoren: Legal information environment and utilization of eresources by undergraduate students at E-library, Faculty of Law, University of Calabar, Nigeria

together in the provision of needed equipment for the e-library to thrive.

2. The e-library sponsors like NUC and CLE, particularly, should ensure that they are alive to their responsibilities by providing statutory e-learning amenities and monitoring the usage.

3. E-library administrators must be professionals as virtual Librarians, being specialists in both Librarianship and the ICT.

\section{References}

Adesoye, A. \& Oyintola, I. (2009). Library information technology usage by graduate students of University of Botswana. An investigation. Gateway Library Journal. 12(2), 150-161.

Ajetunmobi, A. O. (2017). Computers and the law handbook: A resource for lawyers and business professional. Lagos: Princeton Publishing Co. Ltd.

Ajetunmobi, A. O. (2017). Information and communication technology law in Nigeria: A comparative reader. Lagos: Princeton and Associates Publishing Co. Ltd.

Ajifureke, O. (2010). Information technology usage by advertising agencies in Lagos. African Journal of Libraries. Archives and Information Sciences.

American Association of Law Libraries, (2003). Future of law libraries in the digital age. Retrieved from http:// www.aa//net.org/commit/sanarol.

Ani, O. E. (2013).Accessibility and utilization of electronic Information Resources for Research and its effect on productivity of Academic Staff in Nigerian Universities between 2005 and 2013.Unpublished Ph.D Thesis, University of South Africa.

Anigilaje, M. (2005). Current Trends in Technical and Bibliographic services in Law Libraries. NIALS series.
Lagos: NIALS (Nigerian Institute of Advanced Legal Studies).

Dada, T. O. (2000). Organizing law libraries: Policy management and funding of legal education for maximum effect for the $21^{\text {st }}$ century Nigeria. NIALS Law Series, 3(251).

Danner, R. A. (2002). Law school libraries. In Encyclopedia of library and information science. $2^{\text {nd }}$ Edition.

Ellis, D. and Oldman, H. (2005). The English Literature researcher in the age of the Internet, Journal of Information Science 3(1), 29-36.

Francis-Swanson, S. (2010). Information for a new age: Redefining the roles of librariesand librarians. Retrieved from http://www.thevoiceslu.com /features/2010/april/17_04_10/Infor mation_for_a_new_age.htm.

Haavisto, T. (1996).A helping of democracy? Telematics, democracy and Libraries. Retrieved from http://www.ifla. orglio/indexhtm.

Harms, L. (2014). Advanced web search techniques. Florida: Demand Media Inc.

John-Okeke, R. (2003). Law librarianship in the Digital Age: Professional challenges for the developing countries. Lagos Journal of Library and Information Science 1(2): 136141.

Lawal, O. O., Bassey, B. A. \& Ani, O. E. (2008). Resource sharing amongst University law libraries: State of the art. African Journal of Library, Archival and Information Science 18(1), 77-90.

Manzer, B. M. (2002). The abstract journal. Metuchen, N. J: The Scarecrow Press.

Nnadozie, C. O. (2014). Sources of information. In U. Arua, C.P. Uzuegbu \& A. D. Ugah (Eds.) Information literacy education for 
Juliana Nwakaego Agwunobi and Pius Tom Umoren: Legal information environment and utilization of eresources by undergraduate students at E-library, Faculty of Law, University of Calabar, Nigeria

tertiary institutions. Umuahia: Zeh

Communications.

Nwosu, M. C. \& Ottong, E. J. (2014). Information access tools. In U. Arua, C. P. Uzuegbe \& A. D. Ugah. Eds. Information literacy education for tertiary institutions. Lagos: Zeh Communications.

Obasuji, L. (2006). The impact of computer and Internet: Applications on National Agricultural and Research Institutes (NARI's) Library services. Gateway Library Journal, 9(1), 2335.

Odini, C. (1994). The performance of manual indexes and online databases in information retrieval. Library Review, 43(6), 44-49.

Ojokoh, B. A. \& Asaolu, M. F. (2005). Short communication: studies on Internet Access and usage by students of Federal University of Technology, Akure, Nigeria. African Journal of Library, Archives and Information Science 15(2) 149-153.

Olanlokun, S. O. \& Ojo. J. A. (1998). A survey of the effectiveness and coverage of indexing of Nigerian publications from 1986-1996.African Journal of Library, Archives and Information Sciences 8(2) 97-104.

Omekwu, C. (2005). Information technology, legal education and virtual; Libraries. Lagos: NIALS series.
Oyedum, G. U. (2007). Internet use the Library of Federal University of Technology, Minna: A case study. Gateway Library Journal, 10(1) 2332.

Rahman, H. K. (2002). Computer networks. A paradigm shift to library process. International Journal of Computer Science, 22 (1), 39-42.

Reitz, J. M. (2005). Dictionary for library and information sciences. London: Libraries Unlimited.

Sloan, B. (2008). Electronic reference services. Some suggested guideline. Retrieved from http://people.lis.uiu e.edus.26-sloan/guide.html.

Tadasad, P. G. (2010). Internet and university libraries: Some issues in library development. Paper presented at the $45^{\text {th }}$ ALL Library conference, $23^{\text {rd }}-26^{\text {th }}$ December, 2010.

Taiwo, A. (2017). Basic concepts in legal research methodology: A practical guide for masters and doctoral students and their supervisors. Lagos: Princeton and Associates publishing Co. Ltd.

The New Encyclopedia Britannica 6 (1998) .Information processing and Information system. $15^{\text {th }}$ ed. Chicago: Encyclopedia Britannica Inc.

Ugboma, M. U. (2005). The law librarian and globalization: Prospects and challenges. Journal of Library and Information Sciences, 7(1,2) 67-68. 